\title{
The genetic variability of Hungarian Tsigai sheep
}

\author{
SZILVIA KUSZA ${ }^{1}$, ISTVÁN NAGY², TÍMEA NÉMETH, ANDRÁS MOLNÁR ${ }^{3}$, ANDRÁS \\ JÁVOR' and SÁNDOR KUKOVICS ${ }^{3}$
}

\begin{abstract}
${ }^{1}$ Institute of Animal Science, University of Debrecen, Centre of Agriculture Sciences and Engineering, Debrecen, Hungary, ${ }^{2}$ Agricultural Biotechnology Centre, Gödöllö, Hungary, ${ }^{3}$ Research Institute for Animal Breeding and Nutrition, Herceghalom, Hungary
\end{abstract}

\section{Abstract}

Microsatellite analysis was used to estimate the genetic origin, differences, relationship within 10 Hungarian Tsigai populations. The number of alleles was 262 at the 16 examined locus. Fifteen population specific alleles were detected. The mean number of alleles detected per locus ranged from 4.3 (OarAE119) to 11.9 (MAF70). Genetic distance values were calculated from Nei's minimum genetic distance (DA) formula. Phylogenetic tree was constructed using UPGMA algorithm. The results indicated that the genetic difference was negligible between the following populations pair-wise: two Hungarian indigenous populations (Kardoskút1-IN and Kardoskút2-IN); the Hungarian indigenous population Soltszentimre-IN and the Milking Tsigai population Akasztó-ZO; the Hungarian indigenous population Csanádpalota-IN and the transitional type population Makó-Rákos-TR. Microsatellite genotyping prooved to be efficient tool for examing the genetic relationships among Hungarian Tsigai populations.

Keywords: Tsigai populations, microsatellite marker, genetic difference, phylogenetic analysis

\section{Zusammenfassung}

\section{Genetische Vielfalt Ungarischer Zackelschafe}

Es erfolgten Untersuchungen von Mikrosatelliten 10 ungarischer Zackelschaf Populationen zur Bewertung von Unterschieden und der genetischen Herkunft dieser. Bei 16 untersuchten Loci wurden 262 Allele bestimmt. Die durchschnittliche Anzahl an Allelen lag bei 4,3 (Oar AE 119) und 11,9 (MAF70) je Locus. Die genetische Distanz wurde mit Hilfe der minimalen genetischen Abstandsformel (DA) von NEI (1987) und der genetische Baum mit Hilfe des UPGMA Algorithmus bestimmt. Die Ergebnisse zeigen, dass die genetische Distanz zwischen folgenden Bestandspaaren zu vernachlässigen sind: den ungarischen, einheimische Populationen Kardoskút1-IN und Kardoskút2-IN, Csanádpalota-IN und der milchgebenden Akasztó-ZO-Population sowie der Makó-RákosTR welche als Übergang zwischen der ungarischen einheimischen Csanádpalota-IN und der milchgebenden, einheimischen Population angesehen wird. Die Genotypisierung mit Hilfe von Mikrosatelliten wird als geeignetes Mittel zur Untersuchung der genetischen Verhältnisse der Ungarischen Zackelschaf Populationen angesehen.

Schlüsselwörter: Zackelschaf, Microsatellitenmarker, genetische Distanz, Abstammung 


\section{Introduction}

In order to find out the possible methods of preservation for the Tsigai and other indigenous breeds of sheep in the in Central-, Eastern and South European regions the differences and relationships among the sheep populations of the various countries of the region were determined (DUCHEV and GROENEVELD 2006, DUCHEV et al. 2006).

There are different alternatives about history, origin of Tsigai sheep breed. There is a very strong opinion from DRAGANESCU (2003), that all members of this group originated from the Ruda sheep breed of Romania, while several others (e.g. KUKOVICS and JÁVOR 2002, KUSZA et al. 2008) are arguing this statement.

According to BREHM (1903) the Tsigai sheep got into Europe from Small Asia by the Bask people and took this breed along the North part of Mediterranean Sea up to Spain from where these sheep arrived to the British islands as well. An other resource stated (SCHANDL 1953) that there were two parts of the Tsigai migration to Europe, but the origin of the breed was the same as mentioned above. The first part came via North-West Caucasian region following the North coast of Black Sea, reached the Cream peninsula, the region of Azov Sea, South Ukraine, Bessarabia (Moldavia) and the ancient Romania, than to Transylvania, North and South Hungary. The second part came from the South coast of the Black Sea, and started to spread to North following the bed of Danube River, and reached the old Hungarian territories during the second half of the years 1700 .

In Hungary, over the past two hundred years, the Tsigai breed, although in fluctuating ratio (1-10\%), has composed a constant part of sheep stock. Limited number of Tsigai sheep left in Hungary after the I. and II. World War, because the lands, breeding this breed, became abroad.

In order to improve the wool, milk and meat production traits different exotic breeds were used to cross the original Tsigai sheep over the last century. It was the background of the wide variability of the Tsigai sheep (KUKOVICS and JÁVOR 2002 a,b).

However, it could not say that Tsigai sheep is one breed the Hungarian Sheep Breeders' Association decided that these sheep are traditionally divided into two groups base on their phenotype: indigenous and milking (Zomborski) types. On the contrary to this only its colour could change between black and white, via light coffee colour. The adult body weight of the ewes is differing from 30 and $100 \mathrm{~kg}$, and the body measurements also vary within wide range. Great variations could be recorded regarding milk production: The most Tsigai ewes are milked during a 50-200 days milking period (120-150 days in average). Daily milk production of lactating ewes varies between 0.470 I (MARGETIN et al. 1996) up to 1.25 I in Milking type Tsigai flocks (CAPISTRAK et al. 1997, KUKOVICS 2000, KUKOVICS et al. 2006). In milk composition also high differences were found. The fat-, protein- and lactose content varied between 4.6 to $10.1 ; 4.6$ to 7.2 and 3.6 to $5.4 \%$, respectively (KUKOVICS and JÁVOR 2002 a,b). Great variations of wool productivity trait values could be observed in different Tsigai populations (greasy wool weight 2.0.-5.1 kg; clean wool weight 1.4-2.9 kg; staple length $6.0-14.0 \mathrm{~cm}$; fibre diameter $23-40$ microns) (KUKOVICS and JÁVOR 2002 a,b). Therefore Tsigai populations of the different regions could be hardly considered as a particular, single breed. 
The purpose of this work was to carry out genetic characterisation of different Tsigai sheep population in Hungary in order to facilitate their rational development, utilization and conservation.

\section{Material and methods}

\section{Animals}

Hair and blood samples were taken from randomly selected individuals from different herds (Table 1). Pedigree information was available about selected individuals. 3 to 5year-old animals with no shared common ancestor for at least two generations were selected. Numbers of animals studied per breed are presented in Table 4.

Based on the studies of KUKOVICS et al. $(2004,2006) 10$ different Tsigai sheep populations were sampled for this examination. Besides of the four indigenous-, one transitional and two Milking Tsigai flocks bred originally in Hungary, three imported (one from Romania; and two from Serbia) populations were included in the trial. The number of individuals per flock are presented in Table 1. Blood samples were taken from 252 individuals, belonging to three different (imported) flocks. Hair samples with bulbs were taken from the other seven flocks (altogether 317 individuals).

Table 1

The number, type and label of examined Tsigai populations

Typ, Anzahl und Bezeichnung der ungarischen Zackelschaf-Populationen

\begin{tabular}{lccl}
\hline Type & Type of sample & Number & \multicolumn{1}{c}{ Label } \\
\hline \multirow{3}{*}{ Indigenous } & hair & 59 & Soltszentimre-IN \\
& hair & 40 & Kardoskút1-IN** \\
Transitional & hair & 39 & Kardoskút2-IN* \\
Cokanski & hair & 53 & Csanádpalota -IN \\
& hair & 45 & Makó-Rákos-TR** \\
Zomborski or Pivnicki (Milking) & blood & 125 & Debrecen-CO*** \\
& blood & 77 & Debrecen-ZO*** \\
Rusty & hair & 39 & Cegléd-ZO \\
\hline
\end{tabular}

*Körös-Maros National Park, **rather transitional (between indigenous and Milking Tsigai) than indigenous Tsigai population, $\quad * * *$ imported from Serbia, $\quad * * * *$ imported from Jucu, Romania

\section{DNA extraction and microsatellite analysis}

Fresh blood samples $(2 \mathrm{ml})$ were collected in tubes containing EDTA and stored at $-20^{\circ} \mathrm{C}$ until DNA extraction. Hair samples were taken by picking up and collected in paper bags. Genomic DNAs were extracted as previously described (ZSOLNAI and ORBÁN 1999, FAO/IAEA 2004). Loci selection was based on their location in several chormosomes and recommendation of United States Department of Agriculture (USDA); Australian Gene Mapping Web Site; Food and Agricultural Organization (FAO); International Society for 
Animal Genetics (ISAG). Twenty one microsatellite markers were selected first, but finally sixteen of them were studied. The chromosomal location (in parentheses) of the selected ones were as follows: BM6506 (1), OarFCB20 (2), MAF70 (4), MCM527 (5), INRA127 (8), ILSTS11 (9), TGLA53 (12), TGLA357 (14), MAF65 (15), OarCP49 (17), OarAE119 (19), OarCP20 (21), BM1314 (22), MAF35 (23), MCMA7 (25), and CSSM43 (26). Microsatellites were amplified in $25 \mu \mathrm{l}$ volumes, from 10-50 ng DNA template. Polymerase chain reactions (PCRs) were carried out to amplify loci using fluorescent labelled forward primers. Procedure of PCR amplifications and data collection are described by KUSZA et al. 2008.

\section{Statistical analysis}

The number of alleles per locus and heterozygosity values $\left(\mathrm{H}_{\mathrm{obs}}\right.$ and $\mathrm{H}_{\text {exp }}$ ) were estimated using GENEPOP program (RAYMOND-ROUSSET 1995). Populations (v. 1.2.28) and ARLEQUIN (v. 2.0) programmes were used for population datas (LANGELLA 1999, SCHNEIDER et al. 2000). Single locus F-statistics were calculated according to WEIR and COCKERHAM (1984). Genetic distances were estimated from microsatellite data by Population v. 1.2.28 (LANGELLA 1999) using the Nei standard genetic distance (DS) and minimum genetic distance formulas (DA) (NEI 1987). Phylogenetic tree of the populations were constructed by the Populations package using the Neighbor Joining algorithm with 1000 bootstrap on individuals for DA. DRAWGRAM program of the PHYLIP package (v. 3.57c, FELSENSTEIN 1995) was used for the tree drawing.

\section{Results}

\section{Microsatellite loci}

According to our results all loci were polymorphic with the number of alleles per locus ranging from 6 (MAF35) to 26 (INRA127). ILSTS11 marker has 16 allele in Debrecen-CO population, MAF70 marker has the more allele in case of Debrecen-RU, Soltszentimre-IN, Akasztó-ZO, Kardoskút2-IN and Makó-Rákos-TR populations (13, 14, 15, 10 and 14, respectively). The total number of alleles were 262 at the 16 studied loci. The mean number of alleles detected per locus ranged from 4.3 (OarAE119) to 11.9 (MAF70). The expected heterozygosities $\left(H_{\text {exp }}\right)$ varied from 0.567 (BM6506) to 0.846 (BM1314). The observed heterozygosities $\left(\mathrm{H}_{\mathrm{obs}}\right.$ ) varied from 0.323 (OarAE119) to 0.714 (INRA127) (Table 2). Results of $F$ statistics among Hungarian Tsigai populations are showed in Table 2. Mean estimated values for $F_{I T}, F_{S T}$ and $F_{I S}$ were $0.312 ; 0.113$ and 0.226 , respectively. The $F_{I S}$ fixation indice showed high inbreeding within population.

Fifteen alleles were found as population specific allele at 7 loci for the 10 populations (Table 3). CSSM43, MAF35, TGLA53, OarCP20, OarFCB20, MAF70, BM6506, OarAE119 and MAF65 loci were without any specific allele. Distribution of specific alleles were not widespread (1-6).

Distribution of allele frequencies were very widespread. On a few locus there were alleles having high frequency in all examined population (eg. OarCP49 98 allele, MAF35 112 allele, except Cegléd-ZO). 
Table 2

Mean numbers of allele, observed $\left(\mathrm{H}_{\text {obs }}\right)$, expected $\left(\mathrm{H}_{\text {exp }}\right)$ heterozygosities and $\mathrm{F}$ values per locus

Anzahl Allele, ermittelte und geschätzte Zahl der Heterozygotie sowie F-Werte je Locus

\begin{tabular}{lcccccc}
\hline Locus & Mean number of allele per locus & $\mathrm{H}_{\text {obs }}$ & $\mathrm{H}_{\exp }$ & $\mathrm{F}_{\text {IS }}$ & $\mathrm{F}_{\mathrm{ST}}$ & $\mathrm{F}_{\text {IT }}$ \\
\hline MAF35 & 4.5 & 0.648 & 0.648 & 0.001 & 0.057 & 0.057 \\
CSSM43 & 8.9 & 0.617 & 0.777 & 0.205 & 0.115 & 0.296 \\
MCM527 & 7.5 & 0.663 & 0.760 & 0.129 & 0.073 & 0.192 \\
TGLA53 & 10 & 0.711 & 0.822 & 0.135 & 0.075 & 0.200 \\
MCMA7 & 10 & 0.680 & 0.794 & 0.144 & 0.096 & 0.226 \\
OarFCB20 & 6.9 & 0.403 & 0.652 & 0.382 & 0.126 & 0.460 \\
TGLA357 & 8.9 & 0.447 & 0.749 & 0.403 & 0.096 & 0.460 \\
INRA127 & 8.9 & 0.714 & 0.746 & 0.042 & 0.126 & 0.163 \\
MAF70 & 11.9 & 0.499 & 0.803 & 0.378 & 0.081 & 0.429 \\
MAF65 & 5.8 & 0.347 & 0.678 & 0.489 & 0.154 & 0.567 \\
ILSTS11 & 8.0 & 0.668 & 0.768 & 0.131 & 0.128 & 0.242 \\
OarCP20 & 5.9 & 0.496 & 0.731 & 0.321 & 0.076 & 0.373 \\
OarCP49 & 6.1 & 0.593 & 0.663 & 0.106 & 0.039 & 0.141 \\
BM1314 & 10.4 & 0.673 & 0.846 & 0.205 & 0.092 & 0.277 \\
BM6506 & 5.0 & 0.533 & 0.567 & 0.063 & 0.263 & 0.309 \\
OarAE119 & 4.3 & 0.323 & 0.620 & 0.479 & 0.214 & 0.591 \\
Mean & 7.688 & 0.563 & 0.727 & 0.226 & 0.113 & 0.312 \\
\hline
\end{tabular}

Table 3

Population specific alleles

Bestandsspezifische Allele

\begin{tabular}{lcl}
\hline Locus & Allele & Population \\
\hline MCM527 & 176 & Debrecen-ZO \\
MCMA7 & 231 & Soltszentimre-IN \\
& 228 & Soltszentimre-IN \\
& 148 & Cegléd-ZO \\
& 146 & Soltszentimre-IN \\
TGLA357 & 153 & Soltszentimre-IN \\
& 143 & Soltszentimre-IN \\
& 154 & Akasztó-ZO \\
INRA127 & 118 & Kardoskút1-IN \\
& 215 & Csanádpalota-IN \\
ILSTS11 & 180 & Debrecen-CO \\
& 188 & Debrecen-CO \\
OarCP49 & 238 & Debrecen-ZO \\
BM1314 & 97 & Debrecen-CO \\
\hline
\end{tabular}

\section{Population analysis}

The average number of alleles per locus for the populations varied between 6.63 (MakóRákos-TR) and 8.75 (Debrecen-CO). The observed and expected heterozigozities are presented in Table 4. 
Table 4

Mean number of allele. observed and expected heterozygosities and $F_{I S}$ values in the examined Hungarian populations

Durchschnittliche Anzahl Allele, ermittelte und geschätzte Heterozygotie sowie $F_{15}$-Werte der Populationen

\begin{tabular}{lcccc}
\hline Populations & Mean number of allele per population & $\mathrm{H}_{\text {obs }}$ & $\mathrm{H}_{\text {exp }}$ & $\mathrm{F}_{\text {IS }}$ \\
\hline Debrecen-CO & 8.8 & 0.518 & 0.746 & 0.305 \\
Debrecen-ZO & 8.1 & 0.500 & 0.759 & 0.341 \\
Debrecen-RU & 8.1 & 0.594 & 0.766 & 0.225 \\
Cegléd-ZO & 7.2 & 0.552 & 0.694 & 0.205 \\
Soltszentimre-IN & 7.9 & 0.629 & 0.745 & 0.156 \\
Akasztó-ZO & 8.1 & 0.613 & 0.771 & 0.205 \\
Kardoskút1-IN & 8.1 & 0.597 & 0.770 & 0.225 \\
Kardoskút2-IN & 6.7 & 0.584 & 0.718 & 0.192 \\
Csanádpalota-IN & 7.4 & 0.542 & 0.767 & 0.291 \\
Makó-Rákos-TR & 6.6 & 0.506 & 0.724 & 0.299 \\
\hline
\end{tabular}

The mean observed and expected heterozygosities per studied populations were between 0.500-0.629 (Debrecen-ZO-Soltszentimre-IN) and 0.694-0.767 (Cegléd-ZOCsanádpalota-IN), respectively. All examined population was less heterozygous than it was expected.

$F_{\text {IS }}$ value ranged between 0.1556 (indigenous Tsigai) and 0.3406 (Milking Tsigai). The heterozigosity deficit was the highest in Debrecen-ZO population and the smallest in Soltszentimre-IN among examined populations (Table 4).

DA distance was resulted from microsatellite data of population.

Genetic distance between Cegléd-ZO and Kardoskút1-IN (0.922), Kardoskút2-IN (0.947) and between Debrecen-RU and Kardoskút1-IN (0.891), Kardoskút2-IN (0.911) were the largest among the studed Hungarian populations (Table 5, Figure).

Table 5

Matrix of Nei's genetic distances (below diagonal) between the examined Hungarian populations Genetische Distanz (DA) der untersuchten Bestände

\begin{tabular}{lrlllllllll}
\hline \multicolumn{1}{c}{} & Debr-CO & Debr-ZO & Debr-RU & Ceg-ZO & Soltsz-IN Akasztó-ZO Kard1-IN Kard2-IN Csanád-IN Makó-R-TR \\
\hline Debrecen-CO & 0.000 & & & & & & & & & \\
Debercen-ZO & 0.314 & 0.000 & & & & & & & & \\
Debrecen-RU & 0.474 & 0.319 & 0.000 & & & & & & & \\
Cegléd-ZO & 0.509 & 0.322 & 0.242 & 0.000 & & & & & & \\
Soltszentimre-IN & 0.416 & 0.435 & 0.489 & 0.411 & 0.000 & & & & & \\
Akasztó-ZO & 0.399 & 0.362 & 0.414 & 0.352 & 0.144 & 0.000 & & & & \\
Kardoskút1-IN & 0.449 & 0.620 & 0.891 & 0.922 & 0.669 & 0.581 & 0.000 & & & \\
Kardoskút2-IN & 0.527 & 0.641 & 0.911 & 0.948 & 0.744 & 0.651 & 0.103 & 0.000 & & \\
Csanádpalota-IN & 0.545 & 0.485 & 0.594 & 0.603 & 0.407 & 0.381 & 0.311 & 0.244 & 0.000 & \\
Makó-Rákos-TR & 0.639 & 0.476 & 0.481 & 0.513 & 0.411 & 0.326 & 0.545 & 0.492 & 0.175 & 0.000 \\
\hline
\end{tabular}

The Kardoskút1-IN and Kardoskút2-IN; as well as the Soltszentimre-IN and Akasztó-ZO were closest to each other, 0.103 and 0.144 , respectively. Makó-Rákos-TR was considered between Zombori and Indigenous Tsigai, however, it was close to Csanádpalota-IN (0.175) and far from the other examined population. Kardoskút2-IN and Kardoskút1-IN were very close to each other and far from other Hungarian Tsigai groups. The tree suggest that other examined Hungarian Tsigai were genetically closer to each other than Kardoskút2-IN and Kardoskút1-IN populations. It was suprise that Debrecen-RU was close to Cegléd-ZO. 


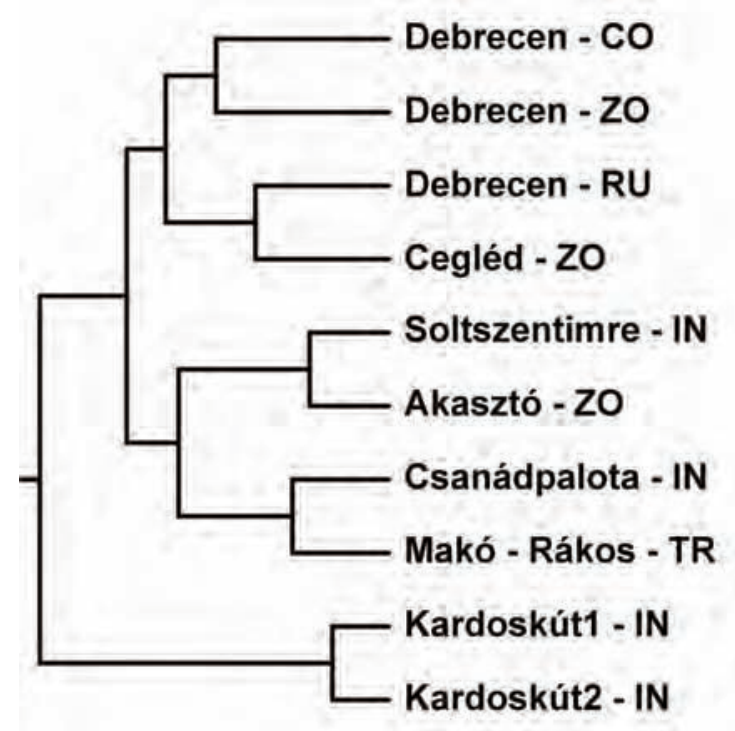

Figure

Dendogramm showing the genetic relationship among Hungarian Tsigai populations using DA distances from 16 microsatellite loci

Genetische Verhältnisse zwischen den Zackelschaf Beständen nach den DA-Werten der 16 Loci

\section{Discussion}

Usually determination of breeds have been based on differencies in their morphological traits. However, in the last years microsatellites markers started to be used to determine the genetic realtionship between breeds instead of traditional blood group or serum protein typing methods (GRIGALIUNAITE et al. 2003, KARPINSKI et al. 2006). In the present study 16 microsatellites were used to estimate the genetic relationship among ten Hungarian Tsigai populations. We found that among Hungarian populations of the first major group, the population from Soltszentimre and Akasztó were closely related, although Soltszentimre-IN has been registered as indigenous Tsigai, while Akasztó-ZO as Milking Tsigai. The Rusty Tsigai (Debrecen-RU) imported from Romania, was improved by Merino and has surprisingly the closest relation to the Milking type population from Cegléd (Cegléd-ZO). The Debrecen-ZO Milking Tsigai population definitively had relations to Cegléd-ZO in the past - this is indeed reflected on the tree. The population from Cegléd is regarded as the most typical Milking type breed in Hungary and has been improved with Serbian (Zomborski and Cokanski) rams in the previous 15 years. The population Debrecen-CO has Cokanski origin.

Two-two populations from Körös-Maros National Park (Kardoskút1-IN and Kardoskút2-IN) and Makó-Rákos-TR and Csanádpalota-IN were in the closest relation according to our results. In the case of the first one, it was easily understandable (both of them were indigenous Tsigai populations), but in the case of the second one, a significant question mark remained. The Tsigai population in Csanádpalota (about 20-25 km from 
Makó-Rákos) was definitely indigenous Tsigai sheep, having no breeding relationship with the one kept and bred in Makó-Rákos. This latter one had refressing breeding stocks (rams) dominantly from the Milking Tsigai flock bred in Cegléd. At the same time (KUKOVICS et al. 2004, 2006) even the body measurements showed a significant distance between these two populations.

GÁSPÁRDY et al. (2004) used 8 microsatellites to determinate the genetic distance among 5 Tsigai populations in Hungary. They found that milking type of Tsigai from Cegléd was very much different from indigenous Tsigai from Jákotpuszta, Kardoskút, Akasztó, Makó. They stated that geographical localization of examined populations was in correlation with their genetic background. They made their own classification as Tsigai sheep from Jákotpuszta called as mountain type, while the others were so called plain type of this breed. This differentiation was not exactly correct because this population in Jákotpuszta was originated from mid Slovakia, having a different breeding background.

The results confirmed the previously known data about the genetic origin of these populations (KUKOVICS et al. 2004), however, some differences were found. In summary we have demonstrated that all sixteen microsatellite markers were able to be amplified in all examined populations and they could be used valuable for the present aim in Tsigai populations.

\section{Acknowledgements}

The authors would like to thank to the Hungarian sheep breeders for helping to collect samples, and to Zsuzsanna Sasvári, Anikó Stágel for their technical help and to Zsuzsanna Bösze for scientific suggestons in the study. This research was financed by European Regional Focal Point in Animal Genetic Resources project, titled: »Possible way of conservation the multipurpose Tsigai and other indigenous sheep breeds in Central-, Eastern European- and Balkan counties« coordinated by Sándor Kukovics (Hungary) and Kristaq Kume (Albania).

\section{References}

Brehm A (1903) Life of Animals. Edited: Méhely L, Bálint S. Légrády Testvérek Press, Budapest, Hungary [in Hungarian]

Capistrac A, Margetin M, Spanic J, Bachyncova T (1997) Milk production and morphological properties of udder in sheep of Tsigay breed and their crosses with Suffolk breed. J Farm Anim Sci 30, 110-18 [in Slovak]

Draganescu C (2003) Romanian strategy for a sustainable management of farm animal genetic resources. Ministry of Agriculture, Forestry, Waters and Environment, Bukarest, 99

Duchev Z, Groeneveld E (2006) Improving the monitoring of animal genetic resources on national and international level. Arch Tierz 49, 532-44

Duchev Z, Distl O, Groeneveld E (2006) Early warning system for loss of diversity in European livestock. Arch Tierz 49, 521-31

FAO/IAEA (2004) Agriculture Biotechnology Laboratory, Handbook of Laboratory Exercises, IAEA Laboratories, Seibersdorf, Austria

Felsenstein J (1995) PHYLIP (Phylogeny Inference Package). University Washington, Seattle, USA

Gáspárdy A, Anton I, Megyerné Nagy J, Fésüs L, Eszes F, Komlósi I (2004) Comparison study of biochemical and DNA polymorphisms in Hungarian Tsigai sheep variants. XXX. Óvar Scientifc Days, Mosonmagyaróvár, 35 [in Hungarian]

Grigaliunaite I, Tapio M, Viinalass H, Grislis Z, Kantanen J, Miceikiene I (2003) Microsatellite variation in the baltic sheep breeds. Veterinarija ir zootechnika. 21, 66-73 
Karpinski M, Junkuszew A, Drozd L, Gruszecki TM (2006) A phylogenetic comparison of wild sheep (Ovis musimon) and domestic sheep (Ovis aries) represented by BCP synthetic line using mitochondrial cytochrome b gene sequence analysis. Arch Tierz 49 Special Issue, 310-6

Kukovics S (2000) Milking Tsigai. In: Jávor A, Fésüs L (eds) Guide book for breeding and breed utilisation. Hungarian Sheep Products' Council, Budapest-Szikszó, 81-2 [in Hungarian]

Kukovics S, Jávor A (2002a) The Tsigai breed and its future. In: Jávor A, Mihók S (eds) Gene preservation; Research results about the values of old domestic animals. Licium Art, Debrecen,103-47 [in Hungarian]

Kukovics S, Jávor A (2002b) The Tsigai sheep. In: Animal Production and Health Compendium, CAB International, London, UK

Kukovics S, Molnár A, Jávor A, Gáspárdy A, Dani Z (2004) Variants and differences in production of Hungarian Tsigai sheep populations; I. Differences in their body size. Állattenyésztés és Takarmányozás 53, 515-28 [in Hungarian]

Kukovics S, Molnár A, Ábrahám M, Németh T, Komlósi I (2006) Effects of udder traits on milk yield of sheep. Arch Tierz 49, 165-75

Kusza Sz, Nagy I, Sasvári Zs, Stágel A, Németh T, Molnár A, Kume K, Bősze Zs, Jávor A, Kukovics S (2008) Genetic diversity and population structure of Tsigai and Zackel type of sheep breeds in the Central-, Eastern- and Southern-European regions. Small Rumin Res 78, 13-23

Langella $O$ (1999) Populations 1.2.28 (12/5/2002): a population genetic software. CNRS UPR9034. http://bioinformatics.org/ tryphon/populations/ [last accessed 24.06.2010]

Margetin M, Capitrak A, Spanic J, Foltys V (1996) Somatic cell count in ewe milk correlated with yield and composition during suckling and milking. . Czech J Anim Sci 41, 543-50 [in Czech]

Nei M (1987) Molecular Evolutionary Genetics. Columbia University Press, New York, NY, USA

Raymond M, Rousset F (1995) Genepop (version 1.2), population genetics software for exact tests and ecumenicism. J Hered 86, 248-9

Schandl J (1953) Sheep breeding. Mezőgazdasági Kiadó, Budapest, Hungary [in Hungarian]

Schnedier S, Roessli D, Excoffier L (2000) Arlequin: A software for population genetic data. Genetics and Biometry Laboratory, University of Geneva, Switzerland

Weir BS, Cockerham CC (1984) Estimating F-statistics for the analysis of population structure. Evolution 38, 1358-70

Zsolnai A, Orbán L (1999) Accelerated separation of random complex DNA patterns in gels: comparing the performance of discontinuous and continuous buffers. Electrophoresis 7, 1462-68 